\title{
Optimizing the performance of photovoltaic cells IBC (interdigitated back contact) by numerical simulation
}

\author{
Nadjat Benadla, Kheireddine Ghaffour \\ Materials and Renewable Energies Research Unit URMER, Faculty of Sciences, Abou Bekr Belkaïd University, Algeria
}

\begin{tabular}{l}
\hline \hline Article Info \\
\hline Article history: \\
Received Mei 1, 2018 \\
Revised Apr 27, 2019 \\
Accepted Jun 26, 2019 \\
\hline
\end{tabular}

\section{Keywords:}

Heterojunction

Interdigitated back contacts cell

Photovoltaic

Simulation under atlas/ silvaco

\begin{abstract}
Solar energy is the most widely shared and abundant source all over the world. This kind of energy is exploited to produce electricity directly by the solar photovoltaic cell. Indeed, siliconphotovoltaic cells are the most widely spread technology. In the present article, we reported a numerical simulation of the interdigitated back contact (IBC) solar cell in order to obtain a higher conversion efficiency. The structure was realized on a p-type multi-crystalline silicon substrate, a p+ type amorphous silicon FSF, an n- type amorphous silicon based emitter, and a p- type BSF. The position of the emitter and the BSF were interdigitated and covered with ohmic contacts. The numerical simulation was carried out by SILVACO software under the Atlas module. The surface of structure was of a value of $10 \mathrm{~cm}^{2}$ under illumination AM1.5g. We studied the effect of the geometrical and the physical parameters of the structure with IBC on the performance of the cell. The optimum obtained conversion efficiency was 20.83\%; this result confirms the potential of the heterojunction silicon technology.
\end{abstract}

Copyright () 2019Institute of Advanced Engineering and Science. All rights reserved.

\section{Corresponding Author:}

Nadjat Benadla,

Materials and Renewable Energies Research Unit URMER, Faculty of Sciences,

AbouBekrBelkaïd University,

Tlemcen Algeria.

Email: benadla_nadjet@live.fr

Kheireddine Ghaffour,

Materials and Renewable Energies Research Unit URMER, Faculty of Sciences,

AbouBekrBelkaïd University,

Tlemcen Algeria.

Email: ghaffourkheireddine@gmail.com

\section{INTRODUCTION}

The importance of solar Photovoltaic (PV) systems is increasing with the ongoing industrial growth and the increased energy demand by developed and developing countries. Energy production by PV systems is becoming one of the main renewable energy sources as it turns the power of the sun into electricity and this can be done repeatedly without causing any damage to the environment [1]. The development of the photovoltaic industry is based on thereduction of manufacturingcosts to make theenergy more competitive with fossil fuels. To achieve this aim, we must reduce the production cost ratio on cell efficiency [2]. One of the most recentproposed technologies is solar cell with Interdigitated Back Contacts (IBC) [3]. This structure was first proposed in the 1970'sand is currently commercially produced by SunPower [4]. It is the highest efficiency solar cell in mass production, but the manufacture of an IBC cell is considerably more complex than that of standard silicon solar cells.

Considerable efforts havebeen made to reduce the cost of solar cell processing [4]. However, the efficiency of existing PV is only about $11-19 \%$ and the best commercial PV is about $23 \%$ [5]. 
In this context, some solutions are proposed. Further investigation must be undertaken in order to minimise the parasitic shunting effect [6]. The IBC structure offers many advantages over conventional solar cells. It, also, improves the aesthetic appearance of the application, and significantly improves the short-circuit current $\left(\mathrm{I}_{\mathrm{SC}}\right)$. This can be achieved through simple interconnection techniques, and higher packing density; in such rear contact structures, shading losses and resistive losses in metal grids can be significantly reduced [7]. They, therefore, make obtaining higher efficiency possible [6]. The output performance of the solar cells in terms of efficiency depends on various factors such as temperature, soiling, and shading; these factors may affect the performance. Hence, maximum power point tracking is the solution for operating the PV system [8].

We have given a representative scheme of IBC cell in Figure1. This structure was realized on a p-type multi-crystalline silicon substrate, a p+ type amorphous silicon FSF, an n-type amorphous siliconbased emitter, and a p-type BSF. The position of the emitter and the BSF were interdigitated, and covered with ohmic contacts. When two semi-conductor materials were in contact, there was an exchange of charges, leading the system to tend towards the thermodynamic equilibrium [3]. To be more determined, this structure was, in fact, a combination between cristallin silicon and amorphous silicon. Henceforth, this amorphous silicon solar cell could be fabricated in a stacked structure to form multijunction solar cells. This strategy was particularly successful for amorphous materials, for many reasons: Firstly, there is no need for lattice matching, as is required for crystalline heterojunctions, secondly, the band gap is readily adjusted by alloying [9], and also, it has a high gap, a low absorption and, finally, a low recombination [3]. Up to now, many researchers have focused on the optimization of the fabrication of Si heterojunction solar cells to increase their efficiency [10]. The main advantage of this kind of cells is the absence of contact on the front face. Rear contact solar cells reduced the rate of shading and achieved potentially higher efficiency by moving all, or part, of the front contact grids to the rear of the device [11]. Such solar cells are especially useful in concentrator applications where the effect of cell series resistance is greater. Auger recombination could be avoided by using an IBC solar cell design where the junction and the contacts were placed at the back of the cell. However, the recombination problem due to the larger surface area remaind unsolved [12].An additional benefit is that cells with both contacts on the rear were easier to interconnect and could be placed closer together in the module since there was no need for a space between the cells. In this article, the characteristics of the structure with IBC were numerically computed, and several variations of geometrical and physical parameters were realized, in the aim to optimize the conversion efficiency factor of the photovoltaic cell. The achieved cell parameters were compared with cell results from ann-type multicrystalline silicon substratemade in the experimental phase.

\section{RESEARCH METHOD}

Modeling is a powerful tool to reproduce mathematically objects and systems. The formalism was based on the physical principles governing the behavior of semi-conductors [6.3], the computation concerned numerical resolution of the two basic charge transport equations in semiconductors, which were respectively the Poisson equation, and the continuity equation for electrons and holes [13]. Numerical simulation was done using Silvaco software under two-dimensionalcomponents. The ATLAS simulator could predict the electrical, optical and thermal behavior of most components semiconductors in steady state. The software consisted to mesh the structure and to numerically compute the solutions of the Poisson equation at each node of the mesh [13]. Figure1 illustrates the cross-section view of the considered IBC solar cells. Table 1 shows thevalues of the geometrical and physical parameters used in the simulation model IBC solar cell.

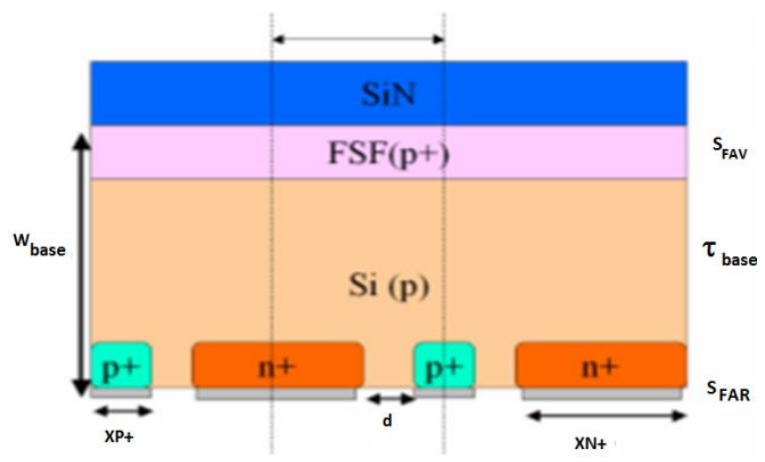

Figure 1. Sectional diagram of the IBC structure [7] 
Table1. Values of the geometrical and physical parameters used

\begin{tabular}{ll}
\multicolumn{2}{c}{ in the simulation model IBC solar cell } \\
\hline Substrate $c-S i$ & $\mathrm{P}$ \\
\hline Length $\mathrm{L}(\mu \mathrm{m})$ & 2000 \\
Thickness $(\mu \mathrm{m})$ & 200 \\
Doping & $5.10^{16}$ \\
ARC & $\mathrm{SiN}$ \\
Thickness $(\mathrm{nm})$ & 75 \\
Emitter a-Si $: \mathrm{H}$ & $\mathrm{N}$ \\
Thickness $(\mathrm{nm})$ & 500 \\
Length $\mathrm{L}_{\mathrm{E}}(\mu \mathrm{m})$ & 1750 \\
BSF a-Si $: \mathrm{H}$ & $\mathrm{P}$ \\
Thickness $(\mu \mathrm{m})$ & 1 \\
Length $\mathrm{L}_{\mathrm{BSF}}(\mu \mathrm{m})$ & 170 \\
cathode & $\mathrm{Silver}$ \\
Length $(\mu \mathrm{m})$ & 120 \\
Thickness $(\mu \mathrm{m})$ & 10 \\
Anode & Aluminum \\
Length $(\mu \mathrm{m})$ & 1700 \\
Thickness $(\mu \mathrm{m})$ & 10 \\
\hline
\end{tabular}

\section{RESULTS AND ANALYSIS}

In this work, ATLAS from SILVACO TCAD was used to simulate the process, and extract the electrical characteristics. Silvaco TCAD Tool was used for Virtualfabrication and simulation; it is a simulator used for device characterization [14]. The optimization of the electrical efficiency of the IBC heterojunction solar cell depends on several parameters related to the quality of the material and the geometry of the structure. Figures 2 and 3 illustrate the basic element of the simulated IBC structure.In Table 2, we give the results obtainedcorresponding to the electrical characteristics. The simulated structure was implemented in the Deckbuild software. The meshing was optimized after a lot of runs until reaching the high precision.

Table2. Electrical characteristics of IBC cell

\begin{tabular}{cccc}
\hline $\mathrm{ISC}\left(\mathrm{mA} / \mathrm{cm}^{2}\right)$ & $\mathrm{VCO}(\mathrm{v})$ & $\mathrm{FF}$ & $\mathrm{EFF}(\%)$ \\
\hline 31.46 & 0.746 & 0.82 & 19.42 \\
\hline
\end{tabular}

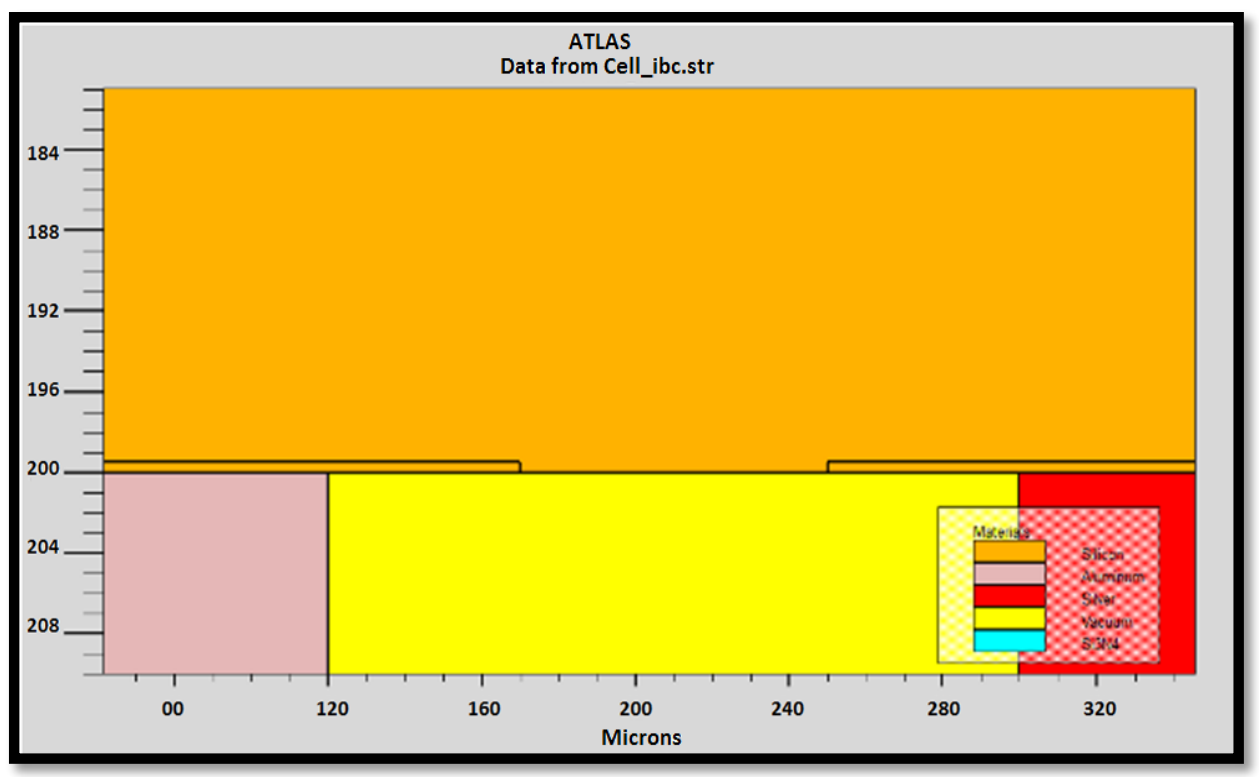

Figure 2. The elementary part simulated under atlas module 


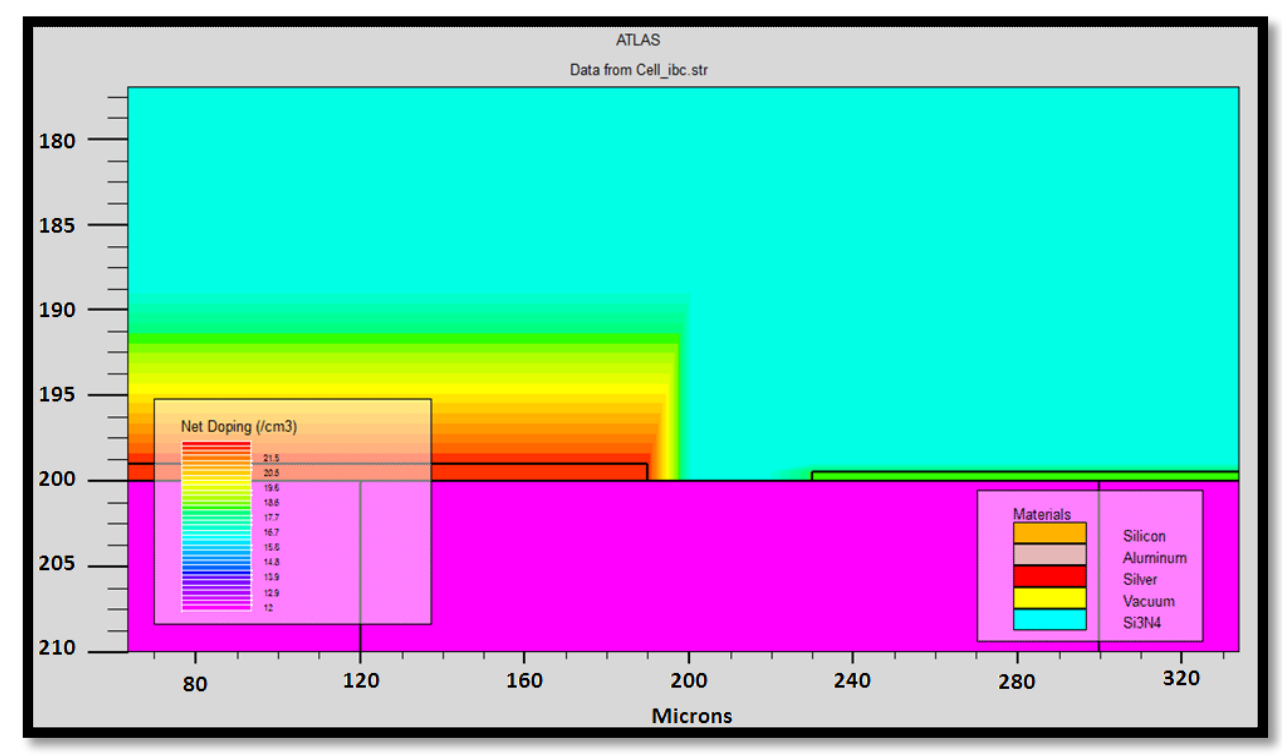

Figure 3. Concentration of the doping of the medium

In order to optimize the geometric and physical parameters, firstly we studied the effect of the BSF $(\mathrm{p}+)$ thickness on the electrical efficiency. We fixed an emitter of $0.5 \mu \mathrm{m}$ and we varied the thickness of BSF $(p+)$. The curve of the electrical efficiency was plotted on Figure 4. This result showed a progressive curve until a maximum of $20.11 \%$ corresponding to a BSF thickness of $1 \mu \mathrm{m}$. Beyond this value, the efficiency factor decreased when BSF thickness increased.In Figure 5, we give numerical results of emitter doping effect on the electrical efficiency. We obtained $20.19 \%$ for a concentration of $5.10^{18} / \mathrm{cm}^{3}$. However, When the doping washigher than $10^{19} / \mathrm{cm}^{3}$, the efficiency decreased due to Auger recombination.

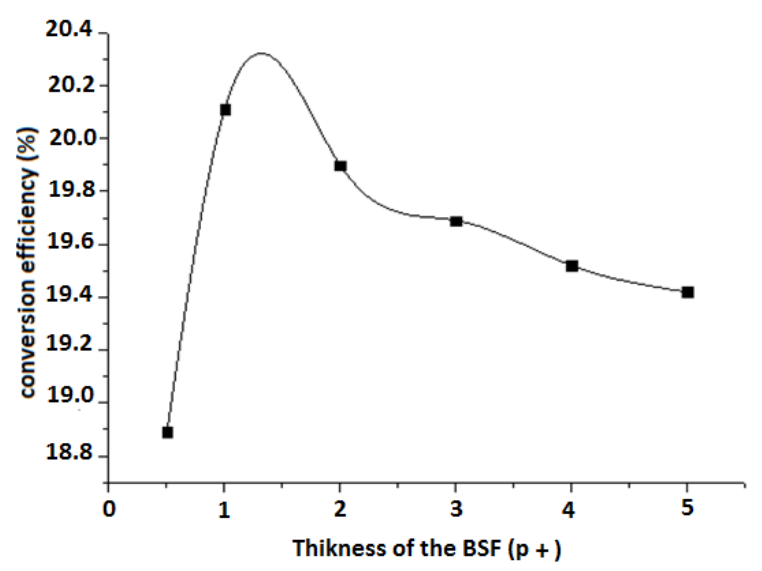

Figure 4. Effect of thickness of the bsf $(\mathrm{p}+)$ on the conversion efficiency factor

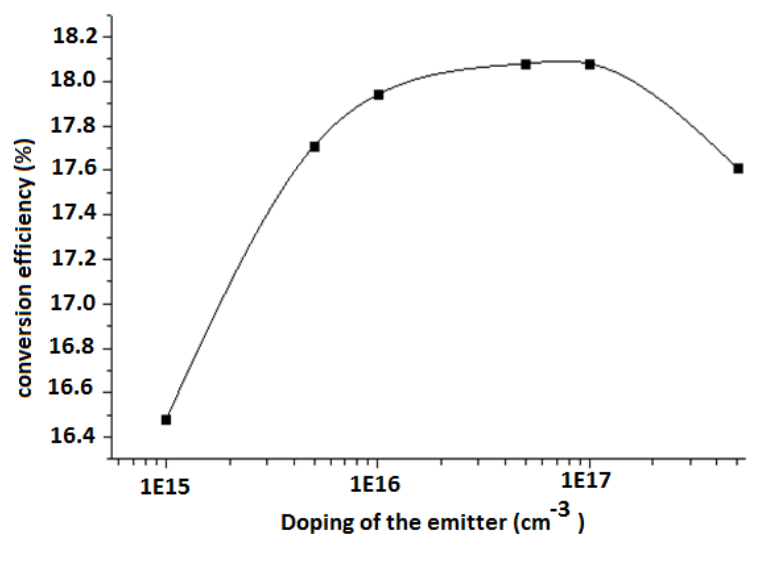

Figure 5. Effect of doping of the emitter on the conversion efficiency factor

The curve of electrical efficiency versus the doping of the BSF is shown in Figure 6. Maximum efficiency of $20.57 \%$ was reached for a concentration of $10^{21} / \mathrm{cm}^{3}$. A strong doping of BSF would reduce the recombination at the level of metal semi-conductor contact where the electrons were pushed by the BSF from the contact to substrate. The variation of the electrical efficiency versus the substrate's doping, is shown in Figure 7. We observe a maximum efficiency of $20.83 \%$ with the concentration $5.10^{16} / \mathrm{cm}^{3}$. We note that the increase in substrate doping led to a decrease in current density ISC, mobility and lifetime of the charge carriers. Figure 8 shows the current/voltage characteristic. 


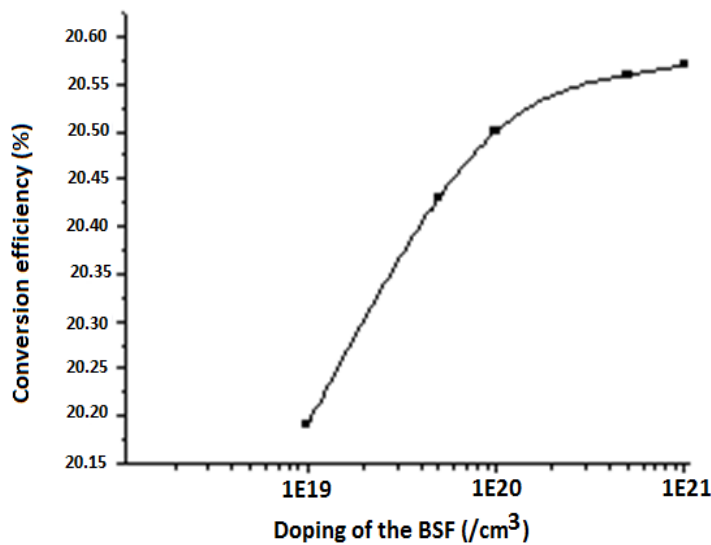

Figure 6. Effect of doping of the BSF on the conversion efficiency factor

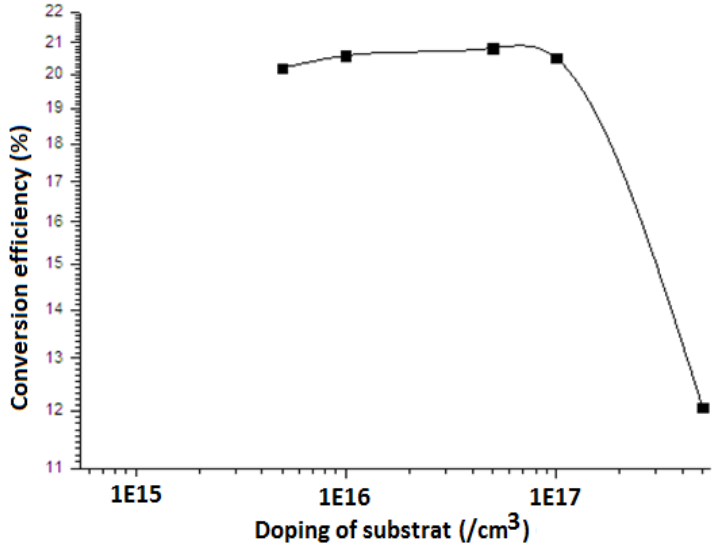

Figure 7. The Effect of Doping of the Substrate on the Conversion Efficiency

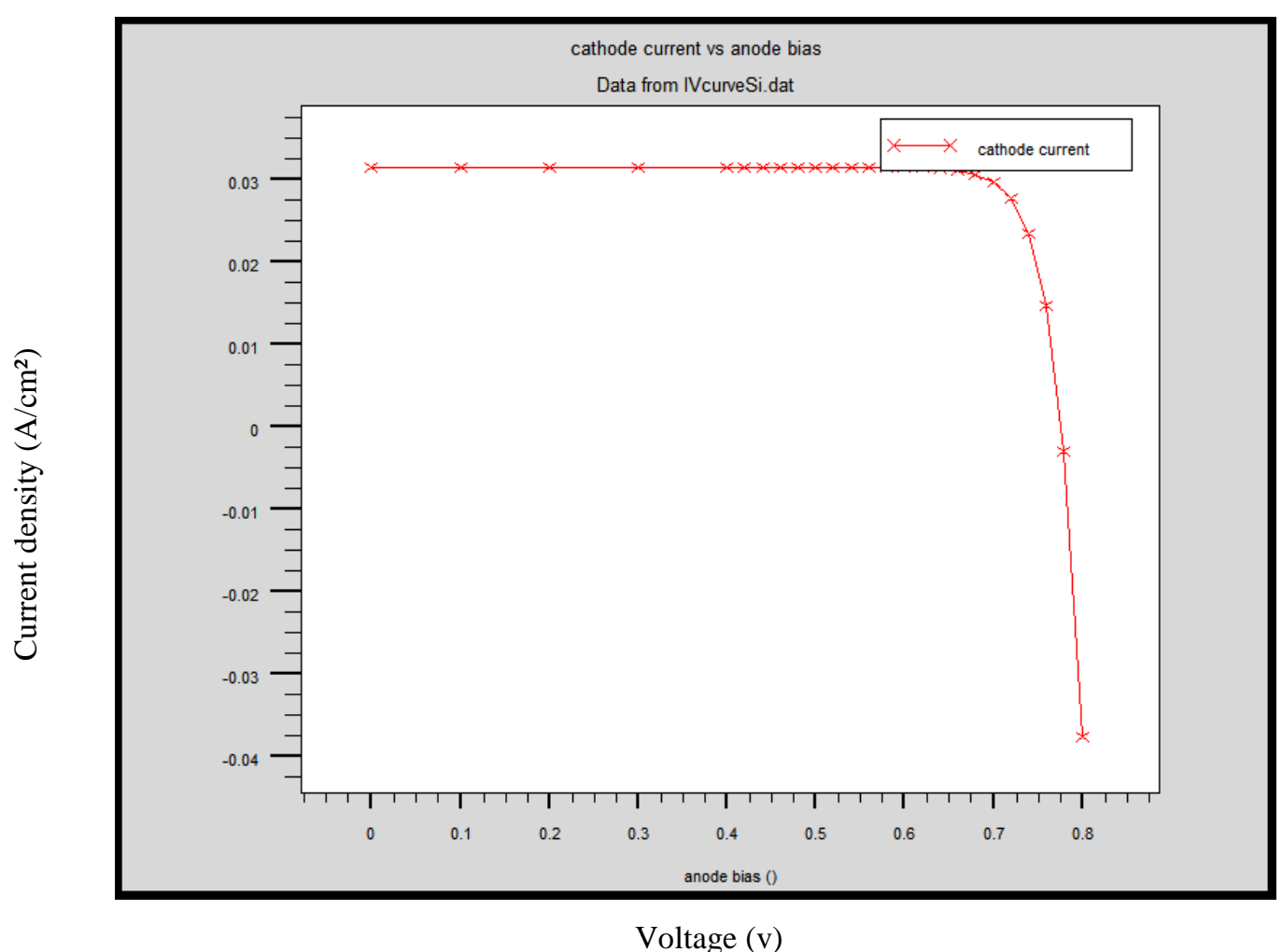

Figure 8. Characteristic I (V) simulated

Figure 9 was obtained by the study of authors Jan Haschkea, Yi-Yang Chena, Ralf Gogolinb, Mathias Mewsa, Nicola Mingirullic, Lars Kortea, and Bernd Rechain in 2013. This team is from Insitute for Silicon-Photovoltaics, Berlin.They investigateonthe fabrication of IBC-SHJ solar celln-type float-zone material with 100 orientation. They devloped a manufacturing IBC cell with the front side. Approximatel, $280 \mu \mathrm{m}$ thick wafer was passivated by a $\mathrm{SiNx} / \mathrm{SiO} 2$ stack and a diffused front surface field. The a-Si:H emitter covered $60 \%$ of the solar cells back side and the BSF $40 \%$. Both, the emitter and the BSF feature were deposited using plasma enhanced chemical vapour deposition (PECVD). 


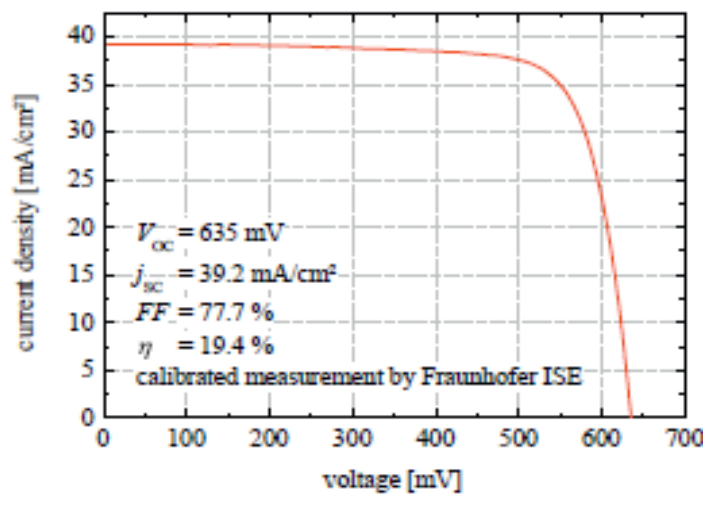

Figure 9. Characteristic i (v) curve IBC cell got in the experimental measurement by fraunhofer ise at stc [15]

The metallisation of the layers is realised by $1.5 \mu \mathrm{m}$ of thermally evaporated aluminium. This technology achieved open circuit voltages of $635 \mathrm{mV}, 39.2 \mathrm{~mA}$ of current circuit and $19.5 \%$ of efficiency.To compare with our research, we noticed that the open circuit voltages is $746 \mathrm{mV}$ and the efficiency is $20,83 \%$. This difference is due to substrate type as well as, to theperformance improvement.

\section{CONCLUSION}

With an emitter located on the rear side, there are fewer recombinations of charge carriers than when it is located on the front side. With this configuration, we obtain higher values of both short-circuit current density ISC and open circuit voltage Vco. The study of geometric and physical parameters effects on the characteristics of the IBC solar cell leads to optimal values of the dimensions and doping of the rear zone (BSF). The best electrical efficiency obtained in our numerical simulation is $20.83 \%$ for concentrations of $5.10^{16} / \mathrm{cm} 3,10^{21} / \mathrm{cm}^{-3}$ and $5.10^{18} / \mathrm{cm}^{-3}$ of the substrate, BSF and emitter, respectively. The thicknesses are $1 \mu \mathrm{m}$ and $0.5 \mu \mathrm{m}$ for the BSF and the emitter, respectively. Our results show that with the IBC study structure that we have designed, we are achieving a very promising electrical performance.

\section{ACKNOWLEDGEMENTS}

The authors would like to express their gratitude to the laboratory unit Materials and Renewable Energies Research, as well as of Abou Bekr Belkaïd University Tlemcen, Algeria for giving them access to using its materials, including the Silvaco software.

\section{REFERENCES}

[1] M .H. Alomari, J. Adeeb, O., "Younis, Solar photovoltaic power forecasting in jordan using artificial neuralnetworks,"International Journal of Electronics and Computer Science Engineering, pp. 497-504, 2018.

[2] B. Benabadji, A.Zarga, "Optimal design of buried emitter of EWT silicon solar cells type by numerical simulation,"Elsevier, vol. 44, pp. 126-131, 2014.

[3] Diouf. D. "Cellules photovoltaiques silicium à hétérojonctions et à structure interdigitée en face arrière," Ph.D. thesis, The Paris -Sud 11 University, 2010.

[4] N. Bateman , P.Sullivan , CH.Reichel, J. Benick, M. Hermle, "High quality ion implanted boron emitters inan interdigitated back contact solar cells with 20\% efficiency,"Elsevier, pp, 509-514, 2011.

[5] A. I. Bin Ibrahim, F. D. Binti Abdul Rahman, M.Bin Rohaizat, "Dual axes solar trcker,"International Journal of Electronics and Computer Science Engineering, pp.1887-1892, 2018.

[6] C.E. Chana, B.J. Hallam, S.R. Wenham, "Simplified interdigitated back contact solar cells,"Elsevier, vol. 27, pp. 543-548, 2012.

[7] E.V. Kerschaver G. beaucarne, "Back contact solar cells : E.V" Prog. Photovolt: Res. Appl, vol 14, pp. 107-123, 2006.

[8] A. Pradhan, B. Panda, "A simplified designand and modeling of boost converter for photovoltaic system,"International Journal of Electronics and Computer Science Engineering, pp.141-149, 2018.

[9] Deng.X, Shiff.A Eric, Amorphous silicon based solar cells,Book of physics Syracuse University Surface, 2003.

[10] H. Fujiwara, M. Kondo, "Impact of epitaxial growth at the heterointerface of a-Si:H/c-Si solar cells,"Appl. Phys. Lett. vol. 90, pp. 013503, 2007.

[11] J.P Joly, Les modules photovoltaïques dans le domaine de la construction, Focus, Mars, 2011.

[12] Hele Savin, Päivikki Repo, al, "Black silicon solarcells with interdigitatedback-contacts achieve $22.1 \%$ efficiency,"Nature nanotechnology, vol. 10, 2015. 
[13] W. Dib, "Modélisations des structures photovoltaiques: Aspects fondamentaux et appliques," Ph.D. thesis, Aboubekr Belkaid Tlemcen University, 2010.

[14] A. M. Tabirkit, A. Guen Bouazza, B. Bouazza, "Modeling and simulationof biaxial strained P-MOSFETs : Application to a signale and dual channel heterostructure"International Journal of Electronics and Computer Science Engineering, pp.421-428, 2018.

[15] Jan Haschke, et al, "Approach for a simplified fabrication process for IBC-SHJsolar cells withhigh fill factors," Elsevier, vol. 38, pp. 732-736, 2013.

\section{BIOGRAPHIES OF AUTHORS}
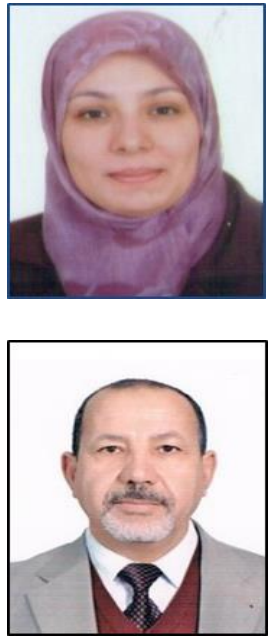

Nadjat Benadla became an Electronic Engineer in 2006 from the university of Tlemcen Algeria. She got the magister degree in microelectronique in 2012 from the University of Tlemcen, and currently, she is a PhD Student at the University of Tlemcen and a member of the research Unit of Materials and Renewable Energy Research (URMER). Her research interests include Strain Silcon Technology, and interdigitated back-contacts solar cells. Email: benadla_nadjet@live.fr

Prof. Ghaffour Kheireddine graduated as an electronics engineer from the "Ecole supérieure d'électricité (Supelec)" in Paris-France in 198. He worked in the field of electrical and optical characterizations of silicon carbide, as part of his magister at the University of Tlemcen in Algeria between 1985 and 1988. His doctoral research work, carried out in alternating training at the "Laboratoire de Physique de la Matière (L.P.M)" of INSA-Lyon-France," focused on the electrical characterization of $\mathrm{SiC}$ diodes using the D.L.T.S technique.His recent research interests include semiconductor device physics and device modeling with a strong emphasis on heterojunction electronic devices and interdigital photovoltaic cells. He is currently a Professor in department of electronic engineering - Faculty of Technology inthe University AbouBekrBelkaïd - Tlemcen13000, Algeria. 